University of Nebraska - Lincoln

DigitalCommons@University of Nebraska - Lincoln

MANTER: Journal of Parasite Biodiversity

Parasitology, Harold W. Manter Laboratory of

9-30-2016

\title{
Viral Zoonoses That Fly with Bats: A Review
}

\author{
Alfonso Calderon \\ Universidad de Cordoba, Monteria, Colombia, alcaran1@yahoo.com \\ Camilo Guzman \\ Universidad de Cordoba, Monteria, Colombia, cguzman40@hotmail.com \\ Jorge Salazar-Bravo \\ Texas Tech University, Lubbock, Texas, USA, j.salazar-bravo@ttu.edu \\ Luiz Tadeu Figueiredo \\ Universidad de Sao Paulo, Brazil, Itmfigue@fmrp.usp.br \\ Salim Mattar \\ Universidad de Cordoba, Monteria, Colombia, mattarsalim@hotmail.com
}

See next page for additional authors

Follow this and additional works at: https://digitalcommons.unl.edu/manter

Part of the Biodiversity Commons, Parasitology Commons, and the Zoology Commons

Calderon, Alfonso; Guzman, Camilo; Salazar-Bravo, Jorge; Figueiredo, Luiz Tadeu; Mattar, Salim; and Arrieta, German, "Viral Zoonoses That Fly with Bats: A Review" (2016). MANTER: Journal of Parasite Biodiversity. 7.

https://digitalcommons.unl.edu/manter/7

This Article is brought to you for free and open access by the Parasitology, Harold W. Manter Laboratory of at DigitalCommons@University of Nebraska - Lincoln. It has been accepted for inclusion in MANTER: Journal of Parasite Biodiversity by an authorized administrator of DigitalCommons@University of Nebraska - Lincoln. 


\section{Authors}

Alfonso Calderon, Camilo Guzman, Jorge Salazar-Bravo, Luiz Tadeu Figueiredo, Salim Mattar, and German Arrieta 
MANTER: Journal of Parasite Biodiversity (ISSN 2470-8224)

Occasional Papers, Number 6, September 30, 2016. http://doi.org/10.13014/K2BG2KWF

MANTER: Journal

Copyright (c) 2016 Calderon, Guzman, Salazar-Bravo, Figueiredo, Mattar, and Arrieta.

This paper was part of a symposium on mammal parasite biodiversity, "CLM20-Zoonosis y mamíferos Neotropicales" [Zoonoses and Neotropical Mammals], presented at III Congreso Latinoamericano de Mastozoología, Bogotá D.C., Colombia, 1 al 5 de diciembre del 2015.

\title{
Viral Zoonoses That Fly with Bats: A Review
}

\section{Alfonso Calderon, ${ }^{1}$ Camilo Guzman, ${ }^{1}$ Jorge Salazar-Bravo, ${ }^{2}$ Luiz Tadeu Figueiredo, ${ }^{3}$ Salim Mattar, ${ }^{1}$ and German Arrieta ${ }^{4}$}

1 Instituto de Investigaciones Biologicas del Trópico, Universidad de Cordoba, Monteria, Colombia; alcaran1@yahoo.com,cguzman40@hotmail.com, mattarsalim@hotmail.com

2 Department of Biological Sciences, Texas Tech University, Lubbock, Texas, USA; j.salazar-bravo@ttu.edu

3 Faculty of Medicine, Institute of Virology, Universidad de Sao Paulo, Brazil; Itmfigue@fmrp.usp.br

4 CECAR Public Health Group, Sincelejo, Sucre, Columbia; arrietager@yahoo.es

\begin{abstract}
Emerging infectious diseases are a growing threat to human health and a great challenge for global medical attention systems. Governmental agencies in tropical regions with abundant zoonotic pathogens should implement an active vigilance/monitoring model in bat reservoir populations because of their species richness, abundance and dispersal capabilities. Chiropterans represent approximately $20 \%$ of all mammal species, the second largest order in terms of number of species after rodents. Importantly, bats constitute natural reservoirs for potential infection of humans of several infectious disease agents such as Coronavirus, Filovirus, Lyssavirus, Paramyxovirus, and Flavivirus. Local disease outbreaks caused by new pathogens can expand globally as a result of human intrusion on wildlife ecosystems and subsequent dispersion of pathogens facilitated by international travel—for example, what happened in 2003 during the severe acute respiratory syndrome pandemic (SARS). At this time, it is not possible to predict which pathogen will cross the species barrier in the future. Nonetheless, a better understanding of a holistic transmission process could help the design of strategies to prevent and control of future pandemics. In this work, we present a summary of the potential societal (economic and epidemiological) effect of disease outbreaks of virus families associated with bats, and the preventive and control measures that could be anticipated.
\end{abstract}

Keywords: tropical medicine, chiropterans, public health, viral diseases

\section{Introduction}

Zoonoses are infectious diseases transmitted from free-living or wild animals to humans by direct contact, ingestion, inhalation, or inoculation of infectious material (Dabanch, 2003). The zoonotic etiology includes infectious agents such as viruses, bacteria, parasites, fungi (Dabanch, 2003; Cabello and Cabello, 2008), and prions (Peralta, 2011; Lee et al., 2013). The existence of a sylvatic reservoir species may facilitate the establishment of a zoonosis in a specific area (Collinge and Ray, 2006; Nelson and Holmes, 2007). Generally, wild or sylvatic reservoir animals are asymptomatic, and the zoonotic disease may infect humans via the action of an arthropod vector or the direct transmission from wild or domestic animals (Cabello and Cabello, 2008; Nelson and Holmes, 2007). This paper summarizes what is known of the potential impact that disease outbreaks of bat-associated viruses may have on public health and the economy, and discusses preventive measures that can be implemented to ameliorate them.

\section{Factors that favor the appearance of zoonoses}

Multiple causes have been suggested to explain the expansion on zoonotic diseases; in principle they start from three 


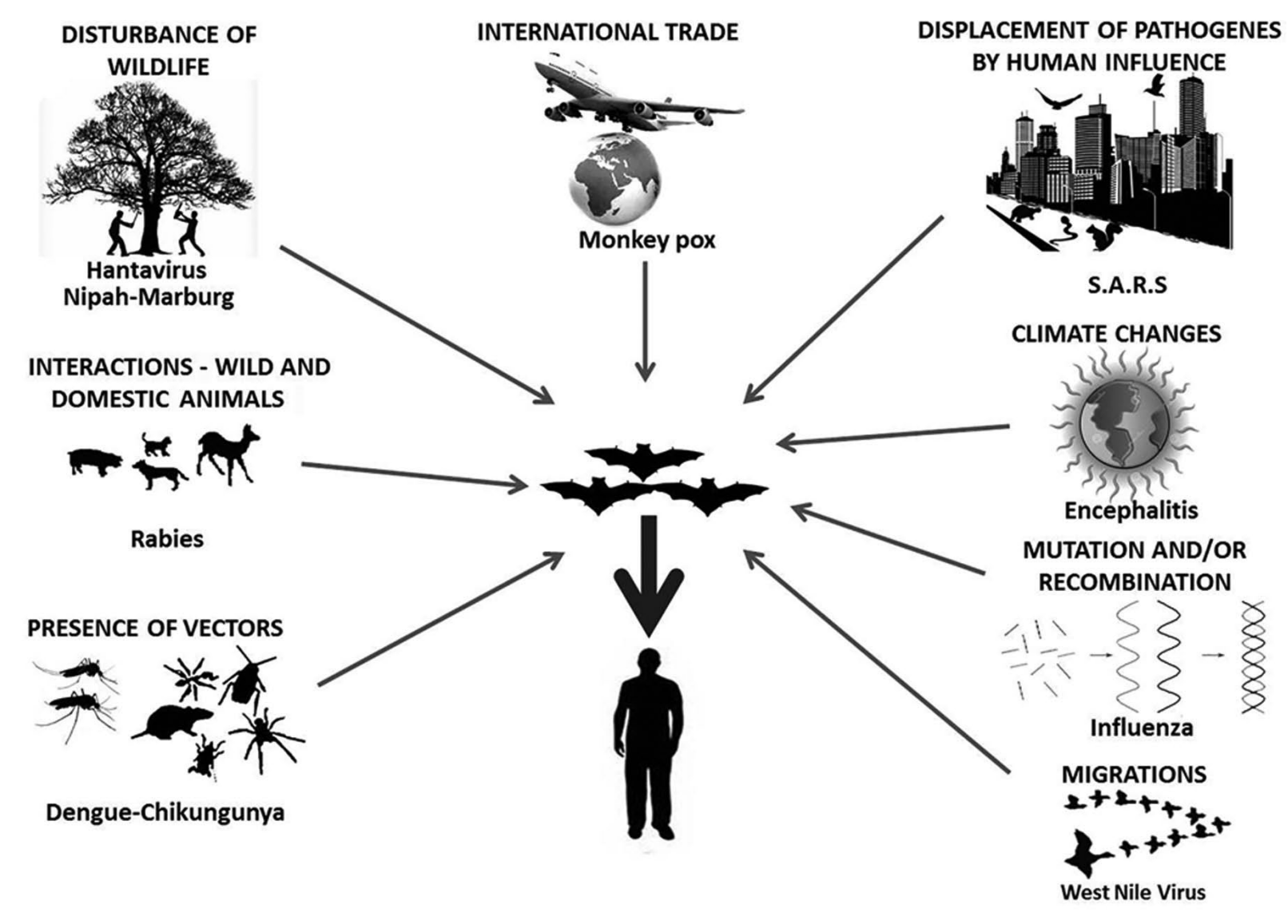

Figure 1. Viral zoonoses that fly.

types of the interactions: a) at the human-animal interface, b) at animal-environment interface, and lastly at c) the human-environment interface: Among a number of specific activities that promote the increase in zoonotic diseases are (Figure 1): habitat modifications that alter the equilibrium in wildlife populations, promote demographic increase in wild reservoirs, and increase the type and number of interactions between humans and animals both wild and domestic (Krause, 1992; Jones et al., 2008); Climate change that causes alterations in the behavior/function of hosts and vectors and that may produce a reduction in the ability to mount an effective immune response (Monsalve et al., 2009) in either, host or vector, or both; Introduction of vectors such as arthropods that mobilize the infection easily in humans-for example, trypanosomiasis, rickettesial infections, Leishmania, Ehrlichia, Chikungunya, zika, dengue, and various forms of encephalitis, all transmitted by insects or acarines (Bender and Shulman, 2004; Parrish et al., 2008; Collinge and Ray, 2006; Daszak et al., 2001; Bengis et al. 2004).
Bats and their importance as zoonotic reservoirs

Chiropterans (bats) are the only truly flying mammals; with over 1,200 species, they represent no less than $20 \%$ of all mammal species and are the second most numerically diverse mammalian order (Ballesteros and Racero, 2012). The number of zoonotic viruses is greater within rodents in comparison with bats, however, on a species-by-species basis bats harbor more viruses (zoonotic and non-zoonotic) than rodents (Luis et al., 2013). There have been more than 60 virus species described from bats, grouped in the following families and genera: Rhabdoviridae — Lyssavirus; Paramyxoviridae-Henipavirus and Rubulavirus; Flaviviridae-Flavivirus; Togaviridae-Alphavirus; Bunyaviridae-Orthobunyavirus, Phlebovirus, and Hantavirus; Reoviridae-Orbivirus and Orthoreovirus; and some viruses that have not yet been classified in Rhabdoviridae and Herpesviridae (Calisher et al., 2006).

Most bat classifications recognize two major groups: Microchiroptera and Megachiroptera. Although it is likely that these groups are not monophyletic (Teeling et al., 2005), this subdivision is useful for didactic purposes. The 
suborder Microchiroptera includes the largest diversity of trophic guilds with many species primarily insectivorous but important numbers of species on other trophic categories, including: piscivores, nectarivorous, frugivores, sanguivores, insectivorous, etc. Megachiroptera comprises species classified into only one family (the Pteropodidae, the flying foxes) and includes species whose feeding habits include plant material - either fruit, nectar, or pollen (Kunz et al., 2011; Moratelli and Calisher, 2015).

\section{Bats and their potential for pathogen dispersion}

The ability of bats to disperse pathogens may be attributed to several different mechanisms: The need to fly great distances in search for food, a long lifespan (up to 35 years), a gregarious behavior that induces the formation of extended local communities with different species inhabiting the same ecological roosting niche, and -in some caseslarge and densely populated roosts. For example, the freetailed bat, Tadarida brasiliensis may roost with up to one million individuals in a single sleeping site [Constantine 1967; Betke et al. 2008]). In a recent review, the sympatric nature of several species roosting in the same cave or cavesystem was identified as an important issue in the potential transmission of pathogens among members of different species of bats (Luis et al., 2013).

The capacity of bats to spread pathogens can also be related to a variety of immunological scenarios; by species that hibernate diminish their metabolic rate during hibernation and therefore may reduce their ability to mount an effective immune response. If this scenario is correct, hibernation may facilitate the multiplication of psychrophilic /enteropathogenic bacteria provoking systemic illness in hibernating species, which in turn may amplify the infectious cycle and infectivity. This scenario was proposed for Yersinia (Mühldorfer, 2013; Blackwood et al., 2013). The noted characteristics have piqued the interest of investigators who are enthusiastically studying the establishment of the zoonotic potential of bats and their relation to public health (Figure 2).

In what follows, we supply an overview on the main viral pathogens isolated from bats that have the potential to cause disease in humans.

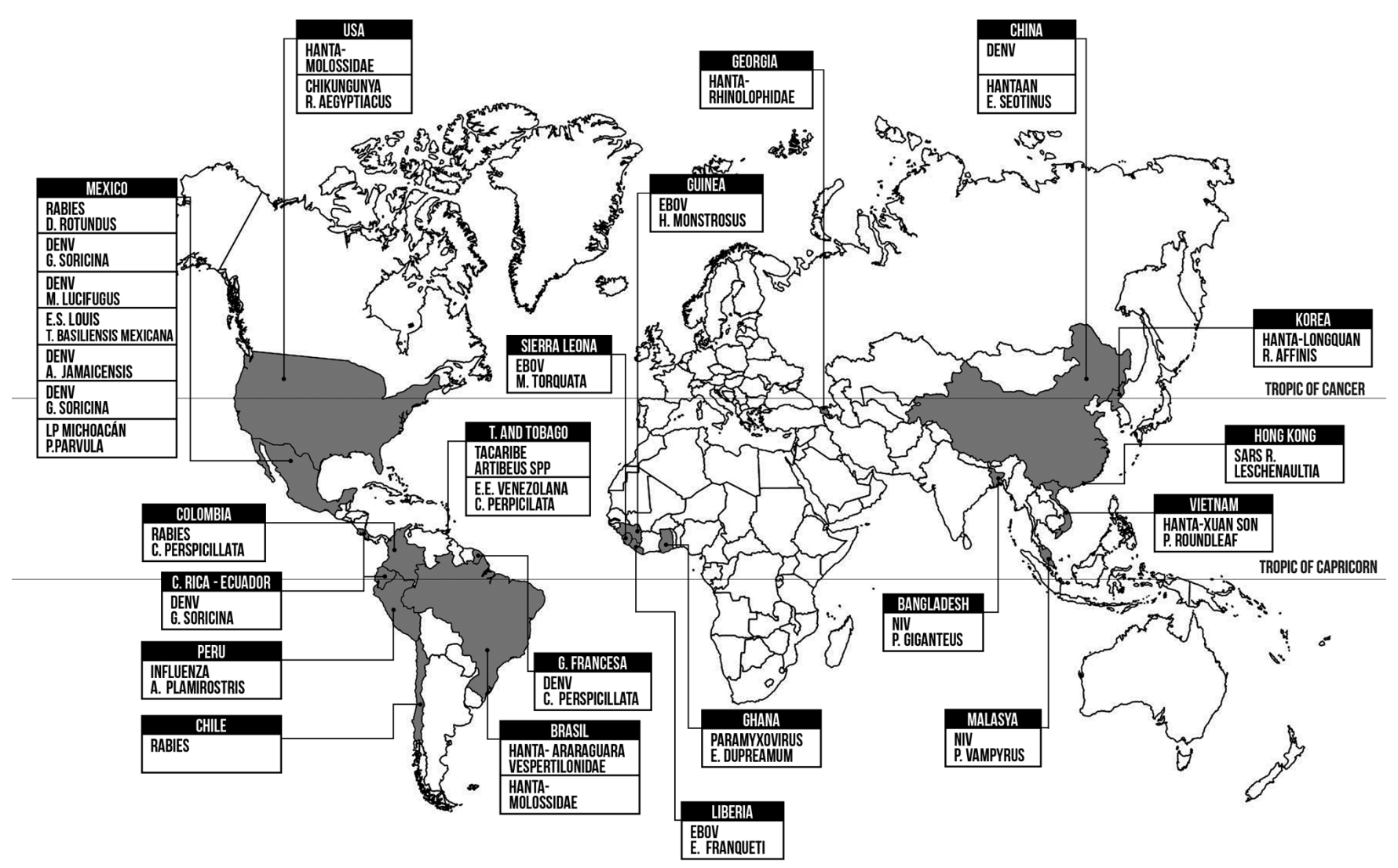

Figure 2. Distribution of some viruses isolated from bats. Please see text for more details. 


\section{Viruses}

\section{Rabies virus}

Without a doubt, this is one of the most infamous viruses transmitted by bats. It is estimated that rabies inflicts over US $\$ 30$ million in costs associated with livestock mortality alone (WHO, 2013).

Both sanguivore and insectivore bat species are known to serve as reservoirs for rabies virus. Only three species of bats are sanguivores: Desmodus rotundus (É. Geoffroy, 1810), Diaemus youngi (Jentink, 1893), and Diphylla ecaudata Spix, 1823, all occurring in the Neotropics (Bogich et al., 2012; Carvalho et al., 2012). Small, but significant, differences exist in their feeding habits, with $D$. rotundus preferring big mammals, while $D$. youngi and $D$. ecaudata usually less numerically dense and therefore less common, tending to prefer bird blood; non-sanguivorous bats are also reservoirs for rabies and maintain independent endemic cycles. In America they have been reported in Brazil (Uieda et al., 1995; De Araújo et al. 2014), Mexico (Loza et al., 2000), Chile (Favi et al., 2002), and Colombia (Núñez et al., 2001). In Colombia the rabies viruses were isolated from Carollia perspicillata (Linnaeus, 1758) (Núñez et al., 2001) and Eptesicus brasiliensis (Desmarest, 1819) (Paéz et al., 2003); also group III rabies viruses have been detected in insectivorous bats such as Molossus, three domestic dogs and one human (Paéz et al., 2003). Since 2000, vampire bats have been the leading cause of human rabies in Latin America and the Caribbean. A continent-wide report suggests that from 2010 to 2012 there was an increase of 5.2\% in bat-transmitted human rabies (Vigilato et al., 2013) and that the effect of the virus appears to be increasing as the virus is emerging in historically Rabies-free areas throughout Latin America (Benavides et al., 2016).

In Colombia two types of transmission cycles have been identified: (1) an urban cycle that circulates primarily among susceptible dogs (dog to dog) but can involve foxes, bovines, horses, and humans, and (2) and a sylvatic cycle, in which sanguivorous (and other) bats are the main reservoirs, but that also may involve bovines, equines, cats, and humans. From the first isolation case of rabies from bats conducted in Colombia (Morales et al., 1968), the country continues to be considered endemic because of the presence of rabies cases linked to bats (Brito et al., 2013; Sarmiento et al. 2015). In northern Brazil, a 2004 outbreak of human rabies was reported (resulting in 20 deaths) that was linked to transmission by Desmodus rotundus (Gupta, 2005).

\section{Hantavirus}

The Hantaan virus was first described in 1978 (Lee et al., 1978). Hantaviruses have been reported on all continents except Australia and may cause illness with high lethality rates: the hantavirus cardiopulmonary syndrome (SCPH) in the Americas and the hemorrhagic fever with renal syndrome (FHSR) in Asia and Europe (Jonsson et al., 2010; Detlev et al., 2015). The reservoirs initially described correspond to small mammals in the order Rodentia (rodents) and Soricomorpha (shrews); these reservoirs either do not get sick, or if so, they quickly recover (Schonrich et al., 2008; Luis et al., 2013; Detlev et al., 2015). Molecular and serological evidence shows that species of bats from several genera (Eptesicus, Rhinolophus, Artibeus, Carollia, Chiroderma, Chrotopterus, Desmodus and Glossophaga) tested positive for hantavirus antibodies and, at least some, may act as reservoirs (Kim et al., 1994; Jung et al., 1995; SabinoSantos et al. 2015). Although there is no hard evidence of transmission of hantavirus from bats to humans (Root et al., 2004; Hinson et al., 2004; Bagamian et al., 2012), hantavirus transmission from human to human was reported for Andes virus (ANDV) (Wells et al., 1997; Martínez et al., 2005), and thus the aerosol transmission from bats to humans is not out of the realm of possibilities..

Cases of Hantavirus Pulmonary Syndrome have been diagnosed in Argentina, Brazil, Paraguay, Bolivia, Chile, Uruguay, Panama, and, recently, in Peru, where numerous viral genotypes have been identified from both humans and rodents (Jonsson et al., 2010; Luiz et al., 2014). In Colombia, in 2004 and 2006 the first serologic studies performed in the Colombian Caribbean were published showing the circulation of hantavirus in humans (Máttar et al., 2004) and in rodents (Alemán et al., 2006) using antigens from the "virus sin nombre" (SNV). Afterwards, in 2011, the genetic identification of a new hantavirus was made in rodents from the Uraba in Colombia (Londoño et al., 2011). In 2012, another study showed the infection in humans with hantavirus antigens from South American strains Maciel and Araraquara (Guzmán et al., 2012), and in 2014 we had the first clinical case in humans (Máttar et al., 2014).

\section{Mammarenavirus}

The mammarenaviruses have a bi-segmented RNA genome consisting of a simple chain and negative sense. The mammarenaviruses are phylogenetically divided into two broad groups: old world and new world. Normally these viruses use rodents as reservoirs, however, Tacaribe (TCRV) is unusual in this respect. This virus occurs in bats and was first isolated from Artibeus jamaicensis palmarum Leach, 1821 and Artibeus jamaicensis trinitatis during a survey of virus surveillance of rabies in Trinidad between 1956 and 1958 (Salazar-Bravo, Ruedas and Yates 2002). Mammarenavirus infect and cause human disease in many parts of the world 
(Charrel et al., 2010). Tacaribe mammarenavirus is, apparently, non-pathogenic to humans and for this reason has proved to be an excellent study model that can be studied without the need for BSL-4 facilities (Martínez et al., 2009). Recently the Tacaribe virus was isolated from the tick Amblyoma americanum Linnaeus, 1758 collected in Florida (Sayler et al., 2014).

\section{Paramyxoviridae}

Two species of Henipavirus (Hendra and Nipa) and two of Rubulavirus (Tioman and Menangle) (Mononegavirales: Paramyxoviridae) were identified as causative agents of independent disease outbreaks in Australasia; symptoms included acute encephalitis, or as an acute influenza-like illness leading to severe respiratory distress, or as meningitis (Marsh et al., 2012; Chua et al., 2001).

Hendra virus, discovered in 1994, was identified in a respiratory disease outbreak that infected 20 horses and two humans, killing all the horses and one of the humans (Smith and Wang, 2013). It has re-appeared several times since the original outbreak (Murray et al., 1995; Marsh et al., 2012). In humans the mortality rate of the infection is $57 \%$. Species of bats in the genus Pteropus are the natural reservoirs and do not show clinical symptoms, even after experimental infection (Williamson et al., 1998; Halpin et al., 2011; Middleton et al., 2007; Field et al., 2001). It has been suggested that the geographic extent of these viruses is limited by the distribution of its host species, as they include Australia, Asia, and islands off East Africa but not continental Africa. Therefore, it was believed that the distribution of henipaviruses could be geographically restricted, until serological and molecular work showed the presence of henipavirus in Eidolon helvum (Kerr, 1792) from Ghana, West Africa, and in Eidolon dupreanum (Pollen in Schlegel and Pollen, 1866) from Madagascar (Hayman et al., 2008; Drexler et al., 2009). Currently, various paramyxoviruses have been described from bats from most continents (Lau et al., 2010; Kurth et al., 2012; Wilkinson et al., 2012; Baker et al., 2012), but the pathogenic potential of these virus in humans is still unknown. A serologic study conducted in Mexico detected a paramyxovirus from the genus Rubulavirus named "La Piedad de Michoacán" virus (LPM) that affected juvenile pigs, Sus scrofa Linnaeus, 1758, producing encephalitis, infertility, and opacity in the cornea (blue eye disease); the precise origin of LPM was not established (Salas et al., 2004); diseases caused by paramyxovirus in other countries have not been reported.

Two major outbreaks of the Nipah virus have taken place since the mid-1990s, one in Malaysia and Singapore and one in Bangladesh and India. The outbreak in Malaysia (September 1998-June 1999) caused respiratory and neurologic illness in pigs. Transmission from pigs to humans produced 283 cases and 109 deaths (39\% lethality). In Singapore 11 cases were reported, with the death of one slaughterhouse worker. The outbreak was controlled by killing more than 1.1 million pigs from the areas at-risk ( $\mathrm{Pa}$ ton et al., 1999). The NiV reservoirs in Malaysia are Pteropus vampyrus (Linnaeus, 1758) and Pteropus hypomelanus Temminck, 1853 (see summary in Yob et al., 2001), and in the case of Bangladesh and India the host species is $P$. giganteus (Brünnich, 1782) (see summaries in Smith and Wang, 2013; Yadav et al., 2012).

\section{Filovirus}

Ebola and Marburg viruses are the only known members of the family Filoviridae; they cause hemorrhagic viral fever (FHV) in humans, greater apes, and other mammals with lethality percentages ranging from $53 \%$ to $90 \%$ (Leroy et al., 2011). The filovirus from the genus Marburgvirus (MARV) comprises only one species, while five strains have been described for Ebola (EBOV) (Kuhn et al., 2010; Barrette et al., 2009). The virus was first detected in 1976 when two simultaneous outbreaks occurred in Nzara (Sudan) and Yambuku (Democratic Republic of the Congo). Fruit-eating bats, in particular Hypsignathus monstrosus Allen, 1861; Epomops franqueti (Tomes, 1860); and Myonycteris torquata (Dobson, 1878), have been suggested as possible natural hosts of the Ebola virus in Africa. The geographic distribution of EBOV may coincide with the distribution of these African bats (Feldmann et al., 2011, 2014). The most recent outbreak of Ebola virus started in December 2013 in southeastern Guinea (West Africa) subsequently spreading to Liberia, Sierra Leone, and other countries, to become the most long-term and most widespread geographically since the discovery of the Ebola virus (de La Vega et al., 2015). At the end of the epidemic over 28,000 suspected, probable and confirmed cases of Ebola virus disease (EVD) were reported, although the true toll of the epidemic, especially the number of deaths, was probably greater. A total of 11,310 deaths was recorded, but the true toll was certainly greater (WHO 2016).

Ebola is spread in the human population from close contact with organs, blood, secretions, or other bodily fluids from animal and human corpses that are infected. In Africa, documented cases of infection are associated with the manipulation of chimps, gorillas, fruit bats, monkeys, antelope, and porcupines that were infected, sick, or dead in the jungle (Olival et al., 2014). Ancestral traditions of contact with the deceased may also be a cause of transmission. Men can transmit the virus through semen even seven weeks after clinical recuperation. Infections of health care personnel happen when treating patients 
with EBOV without having taken the necessary preventive measures in the use of required biosafety equipment (WHO, 2014).

\section{Coronavirus}

Coronaviruses (CoV) are members of the subfamily Coronavirinae, and together with the Torovirinae they form the family Coronaviridae (see King et al., 2012). In 2003 a global outbreak of SARS that started in eastern China and Hong Kong caused 8,422 cases and 916 human deaths (10.9\% lethality) around the world (WHO, 2003). It was believed that the virus went through a quick process of adaptation in an intermediate host (the palm civet, Paguma sp.) before transmission to humans was possible; the fruit bat Rousettus leschenaultia was identified as the reservoir of coronavirus SARS (Li et al., 2005). The outbreak of SARS-CoV was estimated to cost $\$ 54$ million dollars worldwide (Kimball et al., 2004). Coronavirus was detected from bats in Mexico (Machain et al., 2013).

\section{Flavivirus}

The flavivirus (FV) are the cause of important diseases such as dengue, yellow fever, West Nile virus, and San Luis encephalitis virus. Specimens belonging to 5 families, 12 genera, and 19 species of different bats were checked for the dengue virus using ELISA and RT-PCR tests in endemic areas of the Pacific and the Gulf of Mexico, with seropositive results in nine individuals from four different species: the insectivores Myotis nigricans (4/12), Pteronotus parnellii (3/19), and Natalus stramineus (1/4), and one frugivore, Artibeus jamaicensis (1/35). Through RT-PCR, serotype 2 of the dengue virus was detected in 4 samples of 3 species (all from the Gulf coast during the rainy season): two fruit-eating bats, $A$. jamaicensis (2/9) and Carollia brevicauda (1/2), and one insectivore $M$. nigricans (1/11). This last one tested positive simultaneously by serology and molecular biology (Aguilar et al., 2008). In Yucatan (Mexico) during 2010, 140 bats were captured from 7 species. The bats with positive antibodies to the virus belonged to 3 species: the nectarivore Glossophaga soricina and two fruit bats, Artibeus jamaicensis and Artibeus lituratus; flavivirus prevalence was 33\%, 24\%, and $9 \%$, respectively. Each sample of the serum was tested to determine the presence of flavivirus through reverse transcription PCR (RT-PCR), but all samples were negative (Quan et al., 2013). A viral diversity study in bats from Guatemala, Cameroon, Nigeria, Democratic Republic of the Congo, Kenya, and Mexico detected hepacivirus and pegiviruses, a genus recently designated within the family Flaviviridae, and related to the hepatitis virus in humans (Luis et al., 2013; Zhang et al., 1998). The dengue virus was also detected using RT-PCR in bats captured in Hayman, China (Platt et al., 2001). In Ecuador, there are reports of dengue antibodies in bats (Tong et al., 2013).

\section{Influenza virus}

A new subtype of the influenza virus (H17N10) was discovered in fruit-eating bats in Central America, suggesting that other species may transport divergent variants of the influenza virus. In Peru, and via RT-PCR, a new influenza A virus was identified in Artibeus planirostris (Spix, 1823) fruit bats and denoted as (H18N11) (Banyard et al., 2014). (Table 1).

\section{Public Health Measures}

Public health strategies to combat human infection from bat-borne (and other) zoonotic viruses should take into account the ecological and social context of their region. Nonetheless, an understanding of bat ecology and their viral pathogens, as well as the identification of factors that may facilitate an outbreak, could facilitate the control and the reduction of emergent zoonosis. By understanding the triggering mechanisms of an outbreak, management plans and risk mitigation processes can be developed. Once identified, the strategies for risk reduction may be implemented through education of the general public and doctors, veterinarians, and politicians (Smith et al., 2011). According to the ecosocial context, some measures could be useful for reducing the risk of transmission, such as the adequate use of protection equipment in the treatment of patients or animals and restrictions on the commercialization and consumption of wild meat (in countries that consume bat meat). As a result of past outbreaks, public health measures implemented have included improved vigilance and increased infection control for hospitals in the case of SARS, COV, EBOV, and NIV, and during veterinary procedures in the case of Hendra virus, where the use of quarantine and the localization of contacts have been implemented to limit the propagation of the virus (Smith and Wang, 2013). The importance of implementing strategic communication has also been suggested for informing the public with the objective of avoiding the propagation of risk activities (WHO, 2003).

The application of control and prevention measures can be accomplished at different levels. Changes in agricultural practices, such as the creation of dampening barriers between fruit trees and at stables where domestic animals are maintained could significantly reduce the NIV and Hendra virus transmission; this measure has played an important role in the prevention of new NIV outbreaks in 
Table 1. Family and genus of viruses isolated from bats

\begin{tabular}{|c|c|c|c|c|}
\hline Family/genus & Virus & Host & Food source** & Reference \\
\hline \multirow{17}{*}{$\begin{array}{l}\text { Rhabdoviridae/ } \\
\text { Lyssavirus }\end{array}$} & \multirow{2}{*}{ Rabia* } & D. rotundus & Sanguivore & Kim et al. 1994 \\
\hline & & E. brasiliensis & Insectívore & Morales et al. 1968 \\
\hline & \multirow{4}{*}{ Lagos bat } & E. helvum & Frugivore & Tong et al. 2103 \\
\hline & & E. dobosonii & Frugivore & Tong et al. 2103 \\
\hline & & N. gambiensis & Insectivore & Tong et al. 2103 \\
\hline & & E. wahlbergi & Frugivore & Tong et al. 2103 \\
\hline & \multirow{3}{*}{ Duvenhage } & N. noctula & Insectivore & Tong et al. 2103 \\
\hline & & V. murinus & Insectivore & Calisher et al. 2006 \\
\hline & & N. thebaica & Insectivore & Calisher et al. 2006 \\
\hline & \multirow{2}{*}{ A. bat lyssavirus } & Pteropus spp & Frugivore & Calisher et al. 2006 \\
\hline & & S flaviventris & Insectivore & Calisher et al. 2006 \\
\hline & \multirow{2}{*}{ E. bat Lyssavirus 1} & E. serotinus & Insectivore & Calisher et al. 2006 \\
\hline & & R. aegyptiacus & Frugivore & Calisher et al. 2006 \\
\hline & Aravan & M. blyhii & Insectivore & Calisher et al. 2006 \\
\hline & Khujand & M. mystacinus & Insectivore & Calisher et al. 2006 \\
\hline & Irkut & M. leucogaster & Insectivore & Calisher et al. 2006 \\
\hline & W. Caucasian bat & M. schreibersii & Insectivore & Calisher et al. 2006 \\
\hline \multirow{9}{*}{$\begin{array}{l}\text { Bunyaviridae/ } \\
\text { Hantavirus }\end{array}$} & \multirow{2}{*}{ Hantaan } & E. serotinus & Insectivore & Weiss et al. 2012 \\
\hline & & R. ferrumequinum & Insectivore & Weiss et al. 2012 \\
\hline & Magboi & N. hispida & Insectivore & Aguilar et al. 2005 \\
\hline & Mouyassue & N. nanus & Insectivore & Sumibcay et al. 2012 \\
\hline & \multirow{3}{*}{ Longquan } & R. afinis & Insectivore & Guo et al. 2013 \\
\hline & & R. onoceros & Insectivore & Guo et al. 2013 \\
\hline & & R. sinicus & Insectivore & Guo et al. 2013 \\
\hline & Huangpi & P. abramus & Insectivore & Guo et al. 2013 \\
\hline & Xuan son & H. Pomona & Insectivore & Arai et al. 2013 \\
\hline \multirow{9}{*}{$\begin{array}{l}\text { Togaviridae/ } \\
\text { alphavirus }\end{array}$} & \multirow{4}{*}{ Chikungunya } & Scotophilus sp & Insectivore & Arai et al. 2013 \\
\hline & & R. aegyptiacus & Frugivore & Arai et al. 2013 \\
\hline & & H. caffer & Insectivore & Arai et al. 2013 \\
\hline & & C. pumilus & Insectivore & Arai et al. 2013 \\
\hline & \multirow{2}{*}{ Sindbis } & Rhinolophidae sp & Insectivore & Karabatsos, 1985 \\
\hline & & Hipposideridae sp & Insectivore & Karabatsos, 1985 \\
\hline & \multirow{3}{*}{ E. E. Venezolana* } & D. rotundus & Sanguivore & Calisher et al. 2006 \\
\hline & & U. bilobatum & Frugivore & Calisher et al. 2006 \\
\hline & & A. phaeotis & Frugivore & Calisher et al. 2006 \\
\hline \multirow{5}{*}{$\begin{array}{l}\text { Coronaviridae/ } \\
\text { coronavirus }\end{array}$} & \multirow{5}{*}{ S.A.R.S. } & R. leschenautitia & Insectivore & Li et al. 2005 \\
\hline & & R. sinicus & Insectivore & Li et al. 2005 \\
\hline & & R. pearsonii & Insectivore & Li et al. 2005 \\
\hline & & R. macrotis & Insectivore & Li et al. 2005 \\
\hline & & R. ferrumequinum & Insectivore & Li et al. 2005 \\
\hline \multirow{3}{*}{$\begin{array}{l}\text { Filoviridae/ } \\
\text { filovirus }\end{array}$} & \multirow{3}{*}{ Ébola } & H. monstrosus & Frugivore & Leroy et al. 2011 \\
\hline & & E. franqueti & Frugivore & Leroy et al. 2011 \\
\hline & & M. torquata & Frugivore & Leroy et al. 2011 \\
\hline
\end{tabular}


Table 1 (continued). Family and genus of viruses isolated from bats

\begin{tabular}{|c|c|c|c|c|}
\hline Family/genus & Virus & Host & Food source** & Reference \\
\hline \multirow{32}{*}{$\begin{array}{l}\text { Flaviridae/ } \\
\text { Flavivirus }\end{array}$} & Dengue* & M. nigricams & Insectivore & Zhang et al. 1998 \\
\hline & & P. parnellii & Insectivore & Zhang et al. 1998 \\
\hline & & N. stramineus & Insectivore & Zhang et al. 1998 \\
\hline & & A. jamaicensis & Frugivore & Zhang et al. 1998 \\
\hline & Bukalasa* & C. pumilus & Insectivore & Downs et al. 1963 \\
\hline & & T. condylura & Insectivore & Downs et al. 1963 \\
\hline & Carey I. & C. brachiotis & Frugivore & Downs et al. 1963 \\
\hline & & M. minimus & Nectarívoro & Downs et al. 1963 \\
\hline & Dakar & C. pumilus & Insectivore & Downs et al. 1963 \\
\hline & & T. perforates & Insectivore & Downs et al. 1963 \\
\hline & & Scotophilus sp & Insectivore & Downs et al. 1963 \\
\hline & & M. condylurus & Insectivore & Downs et al. 1963 \\
\hline & Entebbe & C. pumilus & Insectivore & Downs et al. 1963 \\
\hline & \multirow{3}{*}{ E. Japonesa } & H. armiger & Insectivore & Downs et al. 1963 \\
\hline & & M. schreibersii & Insectivore & Downs et al. 1963 \\
\hline & & R. cornutus & Insectivore & Downs et al. 1963 \\
\hline & Jugra & C. brachiotis & Frugivore & Downs et al. 1963 \\
\hline & \multirow{4}{*}{ Kyasanu forest } & R. rouxi & Insectivore & Downs et al. 1963 \\
\hline & & C. sphinx & Frugivore & Downs et al. 1963 \\
\hline & & R. rouxi & Insectivore & Downs et al. 1963 \\
\hline & & C. sphinx & Frugivore & Downs et al. 1963 \\
\hline & \multirow{2}{*}{ Río Bravo* } & T. brasiliensis & Insectivore & Varelas et al. 1982 \\
\hline & & E. fuscus & Insectivore & Varelas et al. 1982 \\
\hline & \multirow{2}{*}{ Ponh Penh } & E. spelaea & Pollen & Downs et al. 1963 \\
\hline & & C. brachyotis & Frugivore & Downs et al. 1963 \\
\hline & E. S. Louis* & T. brasiliensis & Insectivore & Downs et al. 1963 \\
\hline & Saboya & N. gambiensis & Insectivore & Downs et al. 1963 \\
\hline & \multirow{2}{*}{ Sokuluk } & N. gambiensis & Insectivore & Price, 1978 \\
\hline & & V. pipistrellus & Insectivore & Downs et al. 1963 \\
\hline & Tamana & P. parnellii & Insectivore & Downs et al. 1963 \\
\hline & \multirow{2}{*}{ Uganda } & Rousettus sp & Frugivore & Downs et al. 1963 \\
\hline & & Tadarida sp. & Insectivore & Downs et al. 1963 \\
\hline \multirow{10}{*}{$\begin{array}{l}\text { Paramyxoviridae/ } \\
\text { Rubulavirus }\end{array}$} & \multirow{3}{*}{ Nipah } & P. pliocephalus & Pollen & L'vov et al. 2014 \\
\hline & & P. scopulatus & Pollen-Fruit & Yob et al. 2001 \\
\hline & & P. conspicillatus & Frugivore & Yob et al. 2001 \\
\hline & \multirow{4}{*}{ Hendra } & P. alecto & Pollen-Fruit & Tajima et al. 2005 \\
\hline & & P. pliocephalus & Frugivore & Epstein et al. 2008 \\
\hline & & P. scopulatus & Pollen-Fruit & Epstein et al. 2008 \\
\hline & & P. conspicillatus & Frugivore & Epstein et al. 2008 \\
\hline & Mapuera & S. Iilium & Frugivore & Epstein et al. 2008 \\
\hline & Mengale & P. pliocephalus & Pollen & Smith et al. 2011 \\
\hline & LP. Michoacán & P.parvula & Insectivore & Paton et al. 1999 \\
\hline \multirow{2}{*}{$\begin{array}{l}\text { Arenaviridae/ } \\
\text { Arenavirus }\end{array}$} & \multirow{2}{*}{ Tacaribe* } & A. lituratus & Frugivore & Downs et al. 1963 \\
\hline & & A. jamaicensis & Frugivore & Downs et al. 1963 \\
\hline
\end{tabular}

* Viruses isolated from bats in America.

** Principal food source 
Malaysia. The introduction of biologic containment measures on pig farms should include vigilance toward animals transferred from other areas and those sent to the slaughterhouse. This is another effective approach that can be applied with relative ease with respect to farming, livestock, and the commercialization of animals (Smith and Wang, 2013). Another measure could be to implement an active vigilance model on different bat populations for the purpose of detecting potential zoonotic agents as well as unknown viruses of low pathogenicity that could recombine with other viruses to become pathogens (Brown, 2004).

Holistic approaches such as ecological studies and a combination of field and laboratory practices will be of great use in creating predictive models that will allow for a better understanding of bioecological aspects and the generation of management options for disease, regardless of the source or virus. For example, a community could establish management options that would reduce the probability of contact between humans and reservoirs during seasonal periods (high risk of a jump between species); such methods could be effective in balancing the conservation needs of biodiversity and the need for human health policies. Finally, the use of new technologies like serological multiplexing and high-efficiency sequencing are being used as an integral part of the efforts to increase our supervision capacity of pre-emergency pathogens with zoonotic potential.

\section{Conclusion}

The widespread geographical distribution of Chiroptera and their viral biodiversity suggests that bats are an important natural reservoir for viruses of growing interest in the transmission of infectious zoonotic diseases with an impact on public health and which also might implicate great economic loses. Knowledge of the distribution of reservoirs and studies on their specific role in the transmission of zoonotic viral agents are necessary to establish risk areas and to contribute to prevention and control.

Public health policies demand a holistic approach that integrates international scientific cooperation. The global Ebola epidemic, for example, showed that it is necessary to conform multidisciplinary teams made up of ecologists, veterinarians, social scientists, and politicians who work together to minimize the impact of zoonotic diseases and at the same time to assume the challenge of coexisting with species that are vital to the ecosystem.

\section{References}

Aguilar-Setién, A.; Loza-Rubio, E.; Salas-Rojas, M.; Brisseau, N.; Cliquet, F.; Pastoret, P.P.; Rojas-Dotor, S.; Tesoro, E.; Kretschmer, R. 2005. Salivary excretion of rabies virus by healthy vampire bats. Epidemiology and Infection 133: 517-522.

Aguilar-Setién, A.; Romero-Almaraz, M.L.; Sánchez-Hernández, C.; Figueroa, R.; Juárez-Palma, L.P.; García-Flores, M.M. 2008. Dengue virus in Mexican bats. Epidemiology and Infection 136: 1678-1683.

Alemán, A.; Iguarán, H.; Puerta, H.; Cantillo, C.; Mills, J.; Ariz, W.; Mattar, S. 2006. First serological evidence of Hantavirus infection in rodents in Colombia. Revista de Salud Pública 8: 1-12.

Arai, S.; Nguyen, S.T.; Boldgiv, B.; Fukui, D.; Araki, K.; Dang, C.N.; Ohdachi, S.D.; Nguyen, N.X.; Pham, T.D.; Boldbaatar, B.; Satoh, H.; Yoshikawa, Y.; Morikawa, S.; Tanaka-Taya, K.; Yanagihara, R.; Oishi, K. 2013. Novel bat-borne Hantavirus, Vietnam. Emerging Infectious Diseases 19: 1159-1161.

Bagamian, K.H.; Towner, J.S.; Kuenzi, A.J.; Douglass, R.J.; Rollin, P.E.; Waller, L.A.; Mills, J.N. 2012. Transmission ecology of sin nombre Hantavirus in naturally infected North American deermouse populations in outdoor enclosures. PLOS One 7: e47731. doi: 10.1371/journal.pone.0047731

Baker, K.S.; Todd, S.; Marsh, G.A.; Crameri, G.; Barr, J.; Kamins, A.O.; Peel, A.J.; Yu, M.; Hayman, D.T.; Nadjm, B.; Mtove, G.; Amos, B.; Reyburn, H.; Nyark, E.; Suu-Ire, R.; Murcia, P.R.; Cunningham, A.A.; Wood, J.L.; Wang, L.F. 2012. Novel, potentially zoonotic paramyxoviruses from the African strawcolored fruit bat, Eidolon helvum. Journal of Virology 87: 1348-1358.

Ballesteros, J.; Racero-Casarrubia, J. 2012. Murciélagos del área urbana en la ciudad de Montería, Córdoba-Colombia. Revista MVZ Córdoba 17: 3193-3199.

Banyard, A.C.; Evans, J.S.; Luo, T.R.; Fooks, A.R. 2014. Lyssaviruses and bats: Emergence and zoonotic threat. Viruses 6: 2974-2990.

Barrette, R.W.; Metwally, S.A.; Rowland, J.M.; Xu, L.; Zaki, S.R.; Nichol, S.T.; Rollin, P.E.; Towner, J.S.; Shieh, W.J.; Batten, B.; Sealy, T.K.; Carrillo, C.; Moran, K.E.; Bracht, A.J.; Mayr, G.A.; Sirios-Cruz, M.; Catbagan, D.P.; Lautner, E.A.; Ksiazek, T.G.; White, W.R.; McIntosh, M.T. 2009. Discovery of swine as a host for the Reston ebolavirus. Science 325: 204-206.

Benavides J.A.; Valderrama W.; Streicker, D.G. 2016. Spatial expansions and travelling waves of rabies in vampire bats. Proceedings of the Royal Society B 283: 20160328. http:// dx.doi.org/10.1098/rspb.2016.0328

Bender, J.B.; Shulman, S.A. 2004. Reports of zoonotic disease outbreaks associated with animal exhibits and availability of recommendations for preventing zoonotic disease transmission from animals to people in such settings. Journal of the American Veterinary Medical Association 224: 1105-1109. 
Bengis, R.G.; Leighton, F.A.; Fischer, J.R.; Artois, M.; Mörner, T.; Tate, C.M. 2004. The role of wildlife in emerging and reemerging zoonoses. Revue Scientifique et Technique (International Office of Epizootics) 23: 497-511.

Betke, M.; Hirsh, D.E.; Makris, N.C.; McCracken, G.F.; Procopio, M.; Hristov, N.I.; Tang, S.; Bagchi, A.; Reichard, J.D.; Horn, J.W.; Crampton, S.; Cleveland, C.J.; Kunz, T.H. 2008. Thermal imaging reveals significantly smaller Brazilian freetailed bat colonies than previously estimated. Journal of Mammalogy 80: 18-24.

Blackwood, J.C.; Streicker, D.G., Altizer, S.; Rohani, P. 2013. Resolving the roles of immunity, pathogenesis, and immigration for rabies persistence in vampire bats. Proceedings of the National Academy of Sciences of the United States of America 110: 20837-20842.

Bogich, T.L.; Olival, K.J.; Hosseini, P.R.; Zambrana-Torrelio, C.; Loh E.; Funk, S.; Brito, I.L.; Epstein, J.H.; Brownstein, J.S.; Joly, D.O.; Levy, M.A.; Jones, K.E.; Morse, S.S.; Aguirre, A.A.; Karesh, W.B.; Mazet, J.A.K.; Daszak, P. 2012. Using mathematical models in a unified approach to predicting the next emerging Infectious disease. pp. 607-618. In: Aguirre, A.A.; Ostfeld, R.S.; Daszak, P. (eds.). New Directions in Conservation Medicine: Applied Cases of Ecological Health. Oxford University Press, New York. 672 pp.

Brito-Hoyos, D.M.; Brito Sierra, E.; Villalobos Álvarez, R. 2013. Distribución geográfica del riesgo de rabia de origen silvestre y evaluación de los factores asociados con su incidencia en Colombia, 1982-2010. Revista Panamericana de Salud Pública 33: 8-14.

Brown, C. 2004. Emerging zoonoses and pathogens of public health significance-an overview. Revue Scientifique et Technique (International Office of Epizootics) 23: 435-442.

Cabello, C.C.; Cabello, F. 2008. Zoonosis con reservorios silvestres: Amenazas a la salud pública y a la economía. Revista Médica de Chile 136: 385-393.

Calisher, C.H.; Childs, J.E.; Field, H.E.; Holmes, K.V.; Schountz, T. 2006. Bats: Important reservoir hosts of emerging viruses. Clinical Microbiology Reviews 19: 531-545.

Carvalho-Costa, F.A.; Tedesqui, V.L.; de Jesus Nascimento Monteiro, M.; Bóia, M.N. 2012. Outbreaks of attacks by hematophagous bats in isolated riverine communities in the Brazilian Amazon: A challenge to rabies control. Zoonoses and Public Health 59: 272-277.

Charrel, R.N.; de Lamballerie, X. 2010. Zoonotic aspects of arenavirus infections. Veterinary Microbiology 140: 213-220.

Chua, K.W.; Wang, L,; Lam, S.K.; Crameri, G.; Yu, M.; Wise, T.; Boyle, D.; Hyatt, A.D.; Eaton, B.T. 2001. Tioman virus, a novel paramyxovirus isolated from fruit bats in Malaysia. Virology 283:215-229.

Collinge, S.K.; Ray, C. 2006. Disease Ecology: Community Structure and Pathogen Dynamics. Oxford University Press, New York. 227 pp.

Constantine, D.G. 1967. Activity patterns of the Mexican freetailed bat. University of New Mexico Press, Albuquerque, New Mexico. 79 pp.
Dabanch, P.J. 2003. Zoonoses. Revista chilena de infectología 20: 47-51.

Daszak, P.; Cunningham, A.A.; Hyatt, A.D. 2001. Anthropogenic environmental change and the emergence of infectious diseases in wildlife. Acta Tropica 78: 103-116.

De Araújo, J.L.; Nascimento, M.E.; Dantas, A.F.; Galiza, G.J.; Pedroso, P.M.; Silva, M.L.; Riet-Correa, F. 2014. Rabies in the insectivorous Pallas's Mastiff bat (Molossus molossus) in northeastern Brazil. Journal of Wildlife Diseases 50: 883-886.

de La Vega, M.A.; Stein, D.; Kobinger, G.P. 2015. Ebolavirus evolution: Past and present. PLOS Pathogens 11: e1005221. doi:10.1371/journal. ppat.1005221

Downs, W.G.; Anderson, C.R.; Spence, L.; Aitken, T.H.; Greenhall, A.H. 1963. Tacaribe virus, a new agent isolated from Artibeus bats and mosquitoes in Trinidad, West Indies. American Journal of Tropical Medicine and Hygiene 12: 640-646.

Drexler, J.F.; Corman, V.M.; Gloza-Rausch, F.; Seebens, A.; Annan, A.; Ipsen, A.; Kruppa, T.; Müller, M.A.; Kalko, E.K.V.; Adu-Sarkodie, Y.; Oppong, S.; Drosten, C. 2009. Henipavirus RNA in African bats. PLOS One 4: e6367. doi: 10.1371/ journal.pone.0006367

Epstein, J.H.; Prakash, V.; Smith, C.S.; Daszak, P.; McLaughlin, A.B.; Meehan, G.; Field, H.E.; Cunningham, A.A. 2008. Henipavirus infection in fruit bats (Pteropus giganteus), India. Emerging Infectious Diseases 14: 1309-1311.

Favi, M.; de Mattos, C.A.; Yung, V.; Chala, E.; López, L.R.; de Mattos, C.C. 2002. First case of human rabies in Chile caused by an insectivorous bat virus variant. Emerging Infectious Diseases 8: 79-81.

Feldmann, H. 2014. Ebola-A Growing Threat? New England Journal of Medicine 371: 1375-1378.

Feldmann, H.; Geisbert, T.W. 2011. Ebola haemorrhagic fever. Lancet 377: 849-862.

Field, H.; Young, P.; Yob, J.M.; Mills, J.; Hall, L.; Mackenzie, J. 2001. The natural history of Hendra and Nipah viruses. Microbes and Infection 3: 307-314.

Guo, W.-P.; Lin, X.-D.; Wang, W.; Tian, J.-H.; Cong, M.-L.; Zhang, H.-L.; Wang, M.-R.; Zhou, R.-H.; Wang, J.-B.; Li, M.-H.; Xu, J.; Holmes, E. C.; Zhang, Y.-Z. 2013. Phylogeny and origins of hantaviruses harbored by bats, insectivores, and rodents. PLOS Pathogens 9(2): e1003159. doi: 10.1371/journal.ppat.1003159

Gupta, R. 2005. Recent outbreak of rabies infections in Brazil transmitted by vampire bats. Eurosurveillance 10: pii=2831.

Guzmán, C.; Máttar, S.; Levis, S.; Pini, N.; Figueiredo, L.T.; Mills, J.; Salazar-Bravo, J. 2012. Prevalence of antibody to hantaviruses in humans and rodents in the Caribbean region of Colombia determined using Araraquara and Maciel virus antigens. Memórias do Instituto Oswaldo Cruz 108: 167-171.

Halpin, K.; Hyatt, A.D.; Fogarty, R.; Middleton, D.; Bingham, J.; Epstein, J.H.; Rahman, S.A.; Hughes, T.; Smith, C.; Field, 
H.E.; Daszak, P.; Henipavirus Ecology Research Group. 2011. Pteropid bats are confirmed as the reservoir hosts of henipaviruses: A comprehensive experimental study of virus transmission. American Journal of Tropical Medicine and Hygiene 85: 946-951.

Hayman, D.T.; Suu-Ire, R.; Breed, A.C.; McEachern, J.A.; Wang, L.; Wood, J.L.; Cunningham, A.A. 2008. Evidence of henipavirus infection in West African fruit bats. PLOS One 3: e2739. doi: 10.1371/journal.pone.0002739

Henderson, G.W.; Laird, C.; Dermott, E.; Rima, B.K. 1995. Characterization of Mapuera virus: Structure, proteins, and nucleotide sequence of the gene encoding the nucleocapsid protein. Journal of General Virology 76: 2509-2518.

Hinson, E.R.; Shone, S.M.; Zink, M.C.; Glass, G.E.; Klein, S.L. 2004. Wounding: The primary mode of Seoul virus transmission among male Norway rats. American Journal of Tropical Medicine and Hygiene 70: 310-317.

Holmes, E.C.; Zhang, Y.Z. 2015. The evolution and emergence of hantaviruses. Current Opinion in Virology 10: 27-33.

Jones, K.E.; Patel, N.G.; Levy, M.A.; Storeygard, A.; Balk, D.; Gittleman, J.L.; Daszak, P. 2008. Global trends in emerging infectious diseases. Nature 451: 990-993.

Jonsson, C.B.; Figueiredo, L.T.M.; Vapalahti, O. 2010. A global perspective on hantavirus ecology, epidemiology, and disease. Clinical Microbiology Reviews 23: 412-441.

Jung, Y.T.; Kim, G.R. 1995. Genomic characterization of $M$ and S RNA segments of hantaviruses isolated from bats. Acta Virologica 39: 231-233.

Karabatsos, N.; Berge, T.O.; Taylor, R.M.; American Committee on Arthropod-Borne Viruses, Subcommittee on Information Exchange. 1985. International catalogue of arboviruses, 1985: Including certain other viruses of vertebrates. 3rd ed. American Society of Tropical Medicine and Hygiene, San Antonio, Texas.

Kim, G.R.; Lee, Y.T.; Park, C.H. 1994. A new natural reservoir of hantavirus: Isolation of hantaviruses from lung tissues of bats. Archives of Virology 134: 85-95.

Kimball, A.M.; Lober, B.; Kobayashi, J.; Arima, Y.; Fox, L.; Bro, J.; Pautler, N.F. 2004. Reporting, surveillance, and information exchange: The SARS imperative for innovation. pp. 222-275. In: Learning from SARS: Preparing for the Next Disease Outbreak: Workshop Summary. Knobler, S.; Mahmoud, A.; Lemon, S.; Mack, A.; Sivitz, L.; Oberholtzer, K. (eds.), National Academies Press, Washington, DC.

King, A.M.Q.; Adams, M.J.; Carstens, E.B.; Lefkowitz, E.J. (eds.). 2012. Virus Taxonomy: Classification and Nomenclature of Viruses: Ninth Report of the International Committee on Taxonomy of Viruses, Elsevier Academic Press, Amsterdam. $1327 \mathrm{pp}$.

Krause, R.M. 1992. The origins of plagues: Old and new. Science 257: 1073-1078.

Kruger, D.H.; Figueiredo, L.T.M.; Song, J.-W.; Klempa, B. 2015. Hantaviruses-globally emerging pathogens. Journal of Clinical Virology 64: 128-136.
Kuhn, J.H.; Becker, S.; Ebihara, H.; Geisbert, T.W.; Johnson, K.M.; Kawaoka, Y.; Lipkin, W.I.; Negredo, A.I.; Netesov, S.V.; Nichol, S.T.; Palacios, G.; Peters, C.J.; Tenorio, A.; Volchkov, V.E.; Jahrling, P.B. 2010. Proposal for a revised taxonomy of the family Filoviridae: Classification, names of taxa and viruses, and virus abbreviations. Archives of Virology 155: 2083-2103.

Kunz, T.H.; Braun de Torrez, E.; Bauer, D.; Lobova, T.; Fleming, T.H. 2011. Ecosystem services provided by bats. Annals of the New York Academy of Sciences 1223: 1-38.

Kurth, A.; Kohl, C.; Brinkmann, A.; Ebinger, A.; Harper, J.A.; Wang, L.F.; Mühldorfer, K.; Wibbelt, G. 2012. Novel paramyxoviruses in free-ranging European bats. PLOS One 7: e38688. doi: 10.1371/journal.pone.0038688

Lau, S.K.; Woo, P.C.; Wong, B.H.; Wong, A.Y.; Tsoi, H.W.; Wang, M., Lee, P.; Xu, H.; Poon, R.W.; Guo, R.; Li, K.S.; Chang, K.H.; Zheng, B.J.; Yuen, K.Y. 2010. Identification and complete genome analysis of three novel paramyxoviruses, Tuhoko virus 1, 2, and 3, in fruit bats from China. Virology 404: 106-116.

Lee, H.W.; Lee, P.W.; Johnson, K.M. 1978. Isolation of the etiologic agent of Korean hemorrhagic fever. Journal of Infectious Diseases 137: 298-308.

Lee, J.; Kim, S.Y.; Hwang, K.J.; Ju, Y.R.; Woo, H.J. 2013. Prion diseases as transmissible zoonotic diseases. Osong Public Health and Research Perspectives 4: 57-66.

Leroy, E.M.; Gonzalez, J.P.; Baize, S. 2011. Ebola and Marburg haemorrhagic fever viruses: Major scientific advances, but a relatively minor public health threat for Africa. Clinical Microbiology and Infection 17: 964-976.

Li, W.; Shi, Z.; Yu, M.; Ren, W.; Smith, C.; Epstein, J.H.; Wang, H.; Crameri, G.; Hu, Z.; Zhang, H.; Zhang, J.; McEachern, J.; Field, H.; Daszak, P.; Eaton, B.T.; Zhang, S.; Wang, L.F. 2005. Bats are natural reservoirs of SARS-like coronaviruses. Science 310: 676-679.

Londoño, A.F.; Díaz, F.J.; Agudelo, F.P.; Levis, S.; Rodas, J.D. 2011. Genetic evidence of hantavirus infections in wild rodents from northwestern Colombia. Vector-Borne and Zoonotic Diseases 11: 701-708.

Loza, R.E.; Mattos, C.C.; Aguilar, S.A.; Mattos, C.A. 2000. Aislamiento y caracterización molecular de un virus rábico, obtenido de un murciélago no hematófago en la ciudad de México. Veterinaria México 31: 147-152.

Luis, A.D.; Hayman, D.T.; O'Shea, T.J.; Cryan, P.M.; Gilbert, A.T.; Pulliam, J.N.; Mills, J.N.; Timonin, M.E.; Willis, C.K.; Cunningham, A.A.; Fooks, A.R.; Rupprecht, C.E.; Wood, J.L.; Webb, C.T. 2013. A comparison of bats and rodents as reservoirs of zoonotic viruses: Are bats special? Proceedings of the Royal Society B: Biological Sciences 1;280: 20122753. doi: 10.1098/rspb.2012.2753.

Figueiredo, L.T.M.; de Souza, W.M.; Enria, D.; Ferrer, M. 2014. Hantavirus and cardiopulmonary syndrome in South America. Virus Research 187: 43-54.

L'vov, D.K.; Al'khovskili, S.V.; Shchelkanov, Mlu; Shchetinin, A.M.; Deriabin, P.G.; Gitel'man, A.K.; Samokhvalov, E.I.; Botikov, 
A.G. 2014. Taxonomy of the Sokuluk virus (SOKV) (Flaviviridae, Flavivirus, Entebbe bat virus group) isolated from bats (Vespertilio pipistrellus Schreber, 1774), ticks (Argasidae Koch, 1844), and birds in Kyrgyzstan. Voprosy Virusologii 59: 30-34.

Machain, W.C.; López, U.M.; Talavera, A.L.; Carrillo, N.J.; Vera, E.L.; Puerto, M.; et al. 2013. Serologic evidence of flavivirus infection in bats in the Yucatán Peninsula of México. Journal of Wildlife Diseases 49: 684-689.

Marsh, G.A.; de Jong, C.; Barr, J.A.; Tachedjian, M.; Smith, C.; Middleton, D.; Yu, M.; Todd, S.; Foord, A.J.; Haring, V.; Payne, J.; Robinson, R.; Broz, I.; Crameri, G.; Field, H.E.; Wang, L.-F. 2012. Cedar virus: A novel Henipavirus isolated from Australian bats. PLOS Pathogens 8: e1002836.

Martínez, V.P.; Bellomo, C.; San Juan, J.; Pinna, D.; Forlenza, R.; Elder, M.; Padula, P.J. 2005. Person-to-person transmission of Andes virus. Emerging Infectious Diseases 11: 1848-1853.

Martínez-Sobrido, L.; Emonet, S.; Giannakas, P.; Cubitt, B.; García-Sastre, A.; de la Torre, J.C. 2009. Identification of amino acid residues critical for the anti-interferon activity of the nucleoprotein of the prototypic arenavirus lymphocytic choriomeningitis virus. Journal of Virology 83: 11330-11340.

Mathews, F. 2009. Zoonoses in wildlife integrating ecology into management. Advances in Parasitology 68: 185-209.

Máttar, A.; Garzon, D.; Tadeu, L.; Faccini, M.A.; Mills, J. 2014. Serological diagnosis of hantavirus pulmonary syndrome in a febrile patient in Colombia. International Journal of Infectious Diseases 25: 201-203.

Máttar, S.; Parra, M. 2004. Serologic evidence of hantavirus infection in humans, Colombia. Emerging Infectious Diseases 10: 2263-2264.

Middleton, D.J.; Morrissy, C.J.; van der Heide, B.M.; Russell, G.M.; Braun, M.A.; Westbury, H.A.; Halpin, K.; Daniels, P.W. 2007. Experimental Nipah virus infection in pteropid bats (Pteropus poliocephalus). Journal of Comparative Pathology 136: 266-272.

Monsalve, B.S.; Máttar, S.; González, M. 2009. Zoonosis transmitidas por animales silvestres y su impacto en las enfermedades emergentes y reemergentes. Revista MVZ Córdoba 14: 1762-1773.

Morales, A.A.; Osorno, M.E.; Bernal, C.C.; Lleras, P.A. 1968. Aislamiento de virus rábico de murciélagos en Colombia, $\mathrm{S}$. A. Caldasia 10:167-172.

Moratelli, R.; Calisher, C.H. 2015. Bats and zoonotic viruses: Can we confidently link bats with emerging deadly viruses? Memórias do Instituto Oswaldo Cruz 110: 1-22.

Mühldorfer, K. 2013. Bats and bacterial pathogens: A review. Zoonoses and Public Health 60: 93-110.

Murray, K.; Selleck, P.; Hooper, P.; Hyatt, A.; Gould, A.; Gleeson, L.; Westbury, H.; Hiley, L.; Selvey, L.; Rodwell, B.; Ketterer, P. 1995. A morbillivirus that caused fatal disease in horses and humans. Science 268: 94-97.
Nelson, M.I.; Holmes, E.C. 2007. The evolution of epidemic influenza. Nature Reviews Genetics 8: 196-205.

Núñez, C.L.; Aldaz, J.J.; Escobar, H.; Cuadros, M.E. 2001. Primer hallazgo de rabia silvestre en el murciélago insectívoro Eptesicus brasiliensis en Cali, Colombia. Revista de la Asociación colombiana de ciencias biológicas. 12: 57-61.

Olival, K.J.; Hayman, D.T. 2014. Filoviruses in bats: Current knowledge and future directions. Viruses 6: 1759-1788.

Paéz, A.; Núñez, C.; García, C.; Boshell, J. 2003. Epidemiología molecular de epizootias de rabia en Colombia, 19942002: Evidencia de rabia humana y canina asociada con quirópteros. Biomédica 23: 19-30.

Parrish, C.R.; Holmes, E.C.; Morens, D.M.; Park, E.C.; Burke, D.S.; Calisher, C.H.; et al. 2008. Cross-species virus transmission and the emergence of new epidemic diseases. Microbiology and Molecular Biology Reviews 72: 457-470.

Paton, N.I.; Leo, Y.S.; Zaki, S.R.; Auchus, A.P.; Lee, K.E.; Ling, A.E.; Chew, S.K.; Ang, B.; Rollin, P.E.; Umapathi, T.; Sng, I.; Lee, C.C.; Lim, E.; Ksiazek, T.G. 1999. Outbreak of Nipah-virus infection among abattoir workers in Singapore. Lancet 354: 1253-1256.

Peralta, O.A. 2011. Prion biology and bovine spongiform encephalopathy. Archivos de Medicina Veterinaria 43: 99-109.

Platt, K.B.; Mangiafico, J.A.; Rocha, O.J.; Zaldivar, M.E.; Mora, J.; Trueba, G.; Rowley, W.A. 2001. Detection of dengue virus neutralizing antibodies in bats from Costa Rica and Ecuador. Journal of Medical Entomology 37: 965-967.

Price, J.L. 1978. Isolation of Rio Bravo and a hitherto undescribed agent, Tamana bat virus, from insectivorous bats in Trinidad, with serological evidence of infection in bats and man. American Journal of Tropical Medicine and Hygiene 27: 153-161.

Quan, P.-L.; Firth, C.; Conte, J.M.; Williams, S.H.; ZambranaTorrelio, C.M.; Anthony, S.J., Ellison, J.A.; Gilbert, A.T.; Kuzmin, I.V.; Miezgoda, M.; Osinubi, M.O.V.; Recuenco, S.; Markotter, W.; Breiman, R.F.; Kalemba, L.; Malekani, J.; Lindbalde, K.A.; Rostal, M.K.; Ojeda-Flores, R.; Suzan, G.; Davis, L.B.; Blau, D.M.; Ogunkoya, A.B.; Alvarez Castillo, D.A.; Moran, D.; Ngam, S.; Akaibe, D.; Agwanda, B.; Briese, T.; Epstein, J.H.; Daszak, P.; Rupprecht, C.E.; Holmes, E.C.; Lipkin, W.I. 2013. Bats are a major natural reservoir for hepaciviruses and pegiviruses. Proceedings of the National Academy of Sciences of the United States of America 110: 8194-8199.

Root, J.J.; Black, W.C.; Calisher, C.H.; Wilson, K.R.; Beaty, B.J. 2004. Genetic relatedness of deer mice (Peromyscus maniculatus) infected with sin nombre virus. Vector-Borne and Zoonotic Diseases 4: 149-157.

Sabino-Santos, G., Jr.; Maia, F.G.M.; Vieira, T.M.; de Lara Muylaert, R.; Lima, S.M.; Gonçalves, C.B.; Barroso, P.D.; Melo, M.N.; Jonsson, C.B.; Goodin, D.; Salazar-Bravo, J.; Figueiredo, L.T.M. 2015. Evidence of hantavirus infection among bats in Brazil. American Journal of Tropical Medicine and Hygiene 93: 404-406. 
Salas-Rojas, M.; Sánchez-Hernández, C.; Romero-Almaraz, Md Mde L.; Schnell, G.D.; Schmida, R.K.; Aguilar-Setién, A. 2004. Prevalence of rabies and LPM paramyxovirus antibody in nonhematophagous bats captured in the Central Pacific coast of Mexico. Transactions of the Royal Society of Tropical Medicine and Hygiene 10: 577-584.

Salazar-Bravo, J.; Ruedas, L.; Yates, T.L. 2002. Mammalian reservoirs of Arenaviruses. Current Topics in Microbiology and Immunology 262:25-64.

Sarmiento, R.M.; Brito, G.E.M. 2003. Hallazgo de murciélago de la especie Diphylla ecaudata en Colombia. Informe Quincenal Epidemiológico Nacional 8: 63-68.

Sayler, K.A.; Barbet, A.F.; Chamberlain, C.; Clapp, W.L.; Alleman, R.; Loeb, J.C.; Lednicky, J.A. 2014. Isolation of Tacaribe virus, a Caribbean arenavirus, from host-seeking Amblyomma americanum ticks in Florida. PLOS One 9: e115769. doi: 10.1371/journal. pone.0115769

Schonrich, G.; Rang, A.; Lutteke, N.; Raftery, M.J.; Charbonnel, N.; Ulrich, R.G. 2008. Hantavirus induced immunity in rodent reservoirs and humans. Immunological Reviews 225: 163-189.

Smith, I.; Broos, A.; de Jong, C.; Zeddeman, A.; Smith, C.; Smith, G.; Moore, F.; Barr, J.; Grameri, G.; Marsh, G.; Tachedjain, M.; Yu, M.; Kung, Y.H.; Wang, L.-F.; Field, H. 2011. Identifying Hendra virus diversity in pteropid bats. PLOS One 6: e25275.

Smith, I.; Wang, L.-F. 2013. Bats and their virome: An important source of emerging viruses capable of infecting humans. Current Opinion in Virology 3: 84-91.

Sumibcay, L.; Kadjo, B.; Gu, S.H.; Kang, H.J.; Lim, B.K.; Cook, J.A.; Song, J.-W.; Yanagihara, R. 2012. Divergent lineage of a novel hantavirus in the banana pipistrelle (Neoromicia nanus) in Côte d'Ivoire. Virology Journal 9: 34. doi: 10.1186/1743-422X-9-34

Tajima, S.; Takasaki, T.; Matsuno, S.; Nakayama, M.; Kuranea, I. 2005. Genetic characterization of Yokose virus, a flavivirus isolated from the bat in Japan. Virology 332: 38-44.

Teeling, E.C.; Springer, M.S.; Madsen, O.; Bates, P.; O'Brien, S.J.; Murphy, W.J. 2005. A molecular phylogeny for bats illuminates biogeography and the fossil record. Science 307: 580-584.

Tong, S.; Zhu, X.; Li, Y.; Shi, M.; Zhang, J.; Bourgeois, M.; Yang, H.; Chen, X.; Recuenco, S. Gomez, J.; Chen, L.-M.; Johnson, A.; Tao, Y.; Dreyfus, C.; Yu, W.; McBride, R.; Carney, P.J.; Gilbert, A.T.; Chang, J.; Guo, Z.; Davis, C.T.; Paulson, J.C.; Stevens, J.; Rupprecht, C.E.; Holmes, E.C.; Wilson, I.A.; Donis, R.O. 2013. New world bats harbor diverse influenza $A$ viruses. PLOS Pathogens 9: e1003657. doi: 10.1371/journal.ppat. 1003657

Uieda, W.; Harmani, N.M.S.; Brandão, R. 1995. Raiva em morcegos insetívoros (Molossidae) do Sudeste do Brasil. Revista de Saúde Pública 29: 393-397.

Varelas-Wesley, I.; Calisher, C.H. 1982. Antigenic relationships of flaviviruses with undetermined arthropod-borne status.
American Journal of Tropical Medicine and Hygiene 31: 1273-1284.

Vigilato, M.A.N.; Cosivi, O.; Knöbl, T.; Clavijo, A.; Silva, H.M.T. 2013. Rabies update for Latin America and the Caribbean. Emerging Infectious Diseases 19: 678-679.

Weiss, S.; Witkowski, P.T.; Auste, B.; Nowak, K.; Weber, N.; Fahr, J.; Mombouli, J.-V.; Wolfe, N.D.; Drexler, J.F.; Drosten, C.; Klempa, B.; Leendertz, F.H.; Krueger, D.L. 2012. Hantavirus in bat, Sierra Leone. Emerging Infectious Diseases 18: 159-161.

Wells, R.M.; Sosa Estani, S.; Yadon, Z.E.; Enria, D.; Padula, P.; Pini, N.; Mills, J.N.; Peters, C.J.; Segura, E.L. 1997. An unusual hantavirus outbreak in southern Argentina: Person to person transmission? Hantavirus Pulmonary Syndrome Study Group for Patagonia. Emerging Infectious Diseases 3: 171-174.

Wilkinson, D.A.; Temmam, S.; Lebarbenchon, C.; Lagadec, E.; Chotte, J.; Guillebaud, J.; Ramasindrazana, B.; Héraud, J.M.; de Lamballerie, X.; Goodman, S.M.; Dellaqi, K.; Pascalis, H. 2012. Identification of novel paramyxoviruses in insectivorous bats of the Southwest Indian Ocean. Virus Research 170: 159-163.

Williamson, M.M.; Hooper, P.; Selleck, P.W.; Gleeson, L.J.; Daniels, P.W.; Westbury, H.A., Murray, P.K. 1998. Transmission studies of Hendra virus (equine morbillivirus) in fruit bats, horses, and cats. Australian Veterinary Journal 76 : 813-818.

WHO [World Health Organization]. 2003. Global Alert and Response (GAR). Summary table of SARS cases by country, 1 November 2002-7 August 2003.

WHO [World Health Organization].2013. WHO Expert Consultation on Rabies. Second report. World Health Organization technical report series 982:1-139.

WHO [World Health Organization]. 2014. Case definition recommendations for Ebola or Marburg Virus Diseases. August 9, 2014.

WHO [World Health Organization]. Ebola Response Team. 2016. After Ebola in West Africa: Unpredictable risks, preventable epidemics. New England Journal of Medicine 375: 587-596

Yadav, P.D.; Raut, C.G.; Shete, A.M.; Mishra, A.C.; Towner, J.S.; Nichol, S.T.; Mourya, D.T. 2012. Detection of Nipah virus RNA in fruit bat (Pteropus giganteus) from India. American Journal of Tropical Medicine and Hygiene 87: 576-578.

Yob, J.M.; Field, H.; Rashdi, A.M.; Morrissy, C.; van der Heide, B.; Rota, P.; bin Adzhar, A.; White, J.; Daniels, P.; Jamaluddin, A.; Ksiazek, T. 2001. Nipah virus infection in bats (order Chiroptera) in peninsular Malaysia. Emerging Infectious Diseases 7: 439-441.

Zhang, H.; Yang, X., Li, G. 1998. Detection of dengue virus genome RNA in some kinds of animals caught from dengue fever endemic areas in Hainan Island with reverse transcription-polymerase chain reaction. Zhonghua Shi Yan He Lin Chuang Bing Du Xue Za Zhi 12: 226-228. 